\title{
Analysis of The Implementation Quantum Teaching Method in Teaching English at Five Grade of SDN Bakalrejo 2 in The Academic Year 2016/2017
}

\author{
SANDI YOGA NAURI
}

Universitas Islam Lamongan

\begin{abstract}
:
This research was aimed to analisys implementation of quantum teaching method in teaching English at five grade SDN Bakalrejo 2 academic year 2016/2017 and the problems found in the implementation of quantum teaching method in teaching english at five grade SDN Bakalrejo 2 academic year 2016/2017. This research method is qualitative research. The type of research is descriptive approach. In this study, the types and sources of data used are interview result, field observation results, and data about informants. Data collection methods used in this study include: interview and observation. is through data reduction process, data presentation, and conclusion drawing. The Result research are in the application of Quantum Teaching method in SDN Bakalrejo 2. There are several impacts of the application of Quantum Teaching Method, namely, the spirit and pleasure of students in learning. The problem of implementation Quantum Teaching method providing students with an understanding of the purpose of the lesson and the material being taught, as the ability of each student to understand is different. Furthermore, it provides a stimulation or example of the material to be conveyed. It is also difficult to find relevant media in learning.
\end{abstract}

Keywords: Quantum Teaching, Implementation Quantum Teaching, Problem of Quantum Teaching.

\section{Introduction}

Learning is an active process and function of the total situation surrounding the students. Individuals who do the learning process will take a learning experience and try to find the meaning of these experiences (Pribadi, 2010). Experience deliberately designed to improve the knowledge, skills, and attitudes will lead to the process of learning. Same learning will take students on a memorable learning experience. Experience gained by students will be more memorably obtained if the learning process is the result of the discovery and understanding. In this context, the students experience and do it by themself. The learning process that takes place involves students 
fully to find their own concepts. The involvement of teachers is facilitators and moderators in the learning process.

"English language as a foreign language makes the least use of this language in the community or outside school" (Kasihani, 2010:20). Therefore, activity of teaching English in schools should be effectively implemented so that the students are able to understand the English language very well. One important factor in the success of English language teaching in elementary school is the teacher who teaches English. The teacher who teaches English is a first step and lay the foundation, both academically and psychological. The choice of method or teachingtechnique that is an attractive and appropriate to the age and characteristics of students does not vouch the success of the teaching of the English language if the teacher is not qualified to carry out the activities.

Quantum teaching offers teaching methods that encourage children active in fun learning activities. There are five principles that affect all aspects of Quantum method is, everything speaks, everything aims, before naming experience, admit every effort, if it is worth learning then it is worth also celebrated (Thohir, 2012:3). Teachers have a noble duty to give better knowledge, skills, behavior and morals. But as the rapid information, to make a students to be good people is not easy. To make student will to learn and have a great interest in learning, the teacher must to know and explore the hobby and student happiness. After that, the teacher teaches the knowledge, skills, behaviors, and moral to students.

Moreover, when the application of the method still needs optimizing, so the purpose of the method or technique used in teaching activities have been not achieved well. At the location of the study, the researcher knows that the teaching activities especially in the teaching English. Teacher does not always use Quantum Teaching method. Related to this, researcher wants to know how the application of quantum teaching methods by teacher, what the difficulties are, and what solutions are implemented.

This research question are (1) how is the implementation of quantum teaching method in teaching English at five grade SDN Bakalrejo 2 academic year 2016/2017; (2) what are the problems found in the implementation of quantum teaching method in teaching english at five grade SDN Bakalrejo 2 academic year 2016/2017.

\section{Method}

This research method is qualitative research. Qualitative research is a research procedure that produces descriptive data in the form of written speech of the people and behavior observed. Qualitative research is related to the ideas, perceptions, opinions, or beliefs of the 
observed persons, all of which can not be measured by numbers. Meanwhile, according to Prastowo (2012) qualitative research emphasizes on inductive analysis, not deductive analysis.

The type of research is descriptive approach. Descriptive research is research that seeks to tell the current problem solving based on the data. Qualitative research used in this research is intended to obtain information on the implementation Quantum teaching method in SDN Bakalrejo 2 on the 5 th grade academic year 2016/2017. Moreover, the qualitative approach is expected to be disclosed situation and problems faced in the implementation of Quantum Teaching methods.

In conducting the study, of course, the researcher can not examine all directly. However, it takes a sample or a sample of the entire population to be studied. Samples taken should be able to represent the entire population studied. In this study, the researcher chooses to take a sample of an English teacher who taught the class 5 . Because students are considered more mature and able to accept the methods used with good teachers, especially the use of Quantum Teaching methods.

In this study, the types and sources of data used are:

\section{Primary Data}

According to Hasan (2002: 82) primary data are data obtained or collected directly in the field by the person doing the research or concerned who need it. Primary data can be obtained from individual informant sources such as interviews conducted by researchers.

These primary data include;

- Interview result.

- Field observation results.

- Data about informants.

\section{Secondary Data}

Secondary data is data obtained or collected by people conducting research from existing sources (Hasan, 2002: 58). The data are used to support the primary information that has been obtained from the library materials, literature, previous research, books, and so forth. The resercher get data from interview result, observation in School. The data in this study is the result of the pre-research that has been conducted by the researcher. The researcher took the data from the responden, the teacher of English in 5 Grade SDN Bakalrejo 2.

Data collection methods used in this study include:

1. Interview

The interview is a way to collect information material carried by a question and answer verbally unilaterally face to face, and with the direction and goals have been set. Interviewing techniques used to reveal data about the factors that cause difficulties in learning.

\section{Observation}


The resercher observes from the english teaching process in the classroom. The data gatherided through observation are presented in the form of field note. Data taken by the researcher using this method is the interview record with subject teachers of English.

Data analysis according to Bogdan in Sugiyono (2009: 244) is the process of searching and arranging systematically the data obtained from interviews, field notes, and other materials, so it can be easily understood, and findings can be informed to others. Meanwhile, according to Hasan (2002: 98) qualitative analysis is an analysis that does not use mathematical models, statistical models and certain other models. The analysis process used in this research is by using Miles and Huberman model in Prastowo (2012: 242) that is through data reduction process, data presentation, and conclusion drawing.

\section{Result and Discussion}

For the first, the researcher was summarizing of result in the interview between of researcher and English teacher. The result of interview was the main problem in the teaching process is the students ability to understand was different and some of the materials are difficult to find. So, the teacher used other method to teach the learning material.

The second, the researcher was summarizing of result in the observation for teacher whilst the implementation Quantum teaching Method. The result are some of students enjoy when the teacher used Quantum Teaching Method. The students were looking happy and interesting in teaching process. But, some of students did not understand about the material and the teacher had to give more explanation with other way. The English teacher also could make students understood. Then, English teacher could appreciate and give motivation for students.

The Implementation of Quantum Teaching Method in Teaching English at Five Grade SDN Bakalrejo 2 Academic Year 2016/2017

The Observation was done on April 11th 2017. The first meeting happened at the beginning of every teaching process was the way teacher started the class. The teacher tried to have communication with the students through greetings. The following utterance is one example of greeting done by the teacher and the response of the students in the class.

The teacher : “Good morning students!"

The students: "Good morning, Miss" The teacher : "How are you today?" The students: "I'm fine, and you?" The teacher : "I'm very well, thank you"

After greeting section, the following activity done by the teacher was checking the students' attendance list to check whether there were the students who were absent or not. No 
one was absent from the class; the teacher checked the attendance list of the students by calling them one by one. Then, the teacher started to explain what she wanted to do and gave to the students. The teacher started to teach English and the teacher asked who did not understand about the lesson. The teacher gave the material by using Quantum teaching. The students were looking happy and interested in teaching process. But, some of students did not understand about the material and the teacher must give more explanation with other way. The last, English teacher asked the students about the materials given and the teacher concluded the material. Then, English teacher gave motivation and closed the teaching process.

\section{The result of teaching Activity}

The teacher started the lesson by greeting them and asked the students' condition and checked the attendance list to know whether there were students who were absent or not. It was important because it could make the students more comfortable, then the teacher began to explain about the topics that were going to learn. The teacher also used the examples so that they could understand the lesson easily and got their attention.

When the students were going to be confused and did not know the material. So, the teacher could give more explanation with other method or other way. All of them were able to know the material. The teacher observed their activity and controled their interaction. The teacher also asked the students to remember studying the next material so it could provide their own for the next meeting.

The Problems Found in The Implementation of Quantum Teaching Method in Teaching English at Five Grade SDN Bakalrejo 2 Academic Year 2016/2017

The second discussion is about problem of the implementation Quantum Teaching Method at Five Grade in teaching English. In this discussion, it can be seen the teaching process toward the implementation of Quantum Teaching Method from the result of observation.

The reasearcher has done interview with the English teacher. It has been done to know the condition of Implementation Quantum Teaching Method at the Five grade of SDN Bakalrejo 2 and the problem of them. The result of interview was the main problem in the teaching process when the teacher taught use Quantum Teaching in the classroom. The result of interview was the main problem in the teaching process is the students' abilities to understand were different and some of the materials are difficult to find. So, the teacher uses other method to teach the learning material. From all of data which got through instruments. It can be drawn conclusion that the Implementation Quantum Teaching Method finds the 
problem. The researcher has known the problem from English Teacher at the Five grade in SDN Bakalrejo 2. The problem is that the students' abilities to understand are different and some of the materials are difficult to find relevant media in learning. Futhermore, from observation, the researcher finds that some of students did not understand about the material and the teacher must give more explanation.

For the opening, the teacher made some conversation with students through greetings. English teacher asked the students' condition. After that, English teacher prepared it to make the students easier to understand the lesson.

After doing the pre-activity, the teacher began the activity. English teacher gave materials to the students which have been prepared, when the students were going to be confused and did not know the material. The teacher discussed the students' difficulties during activities and corrected their mistakes using other method or other way. The last, English teacher asked the students about the materials gave and the teacher concluded the material. Then, English teacher gave motivation to the students to do better for the next meeting, and closed the teaching process.

In dealing with some of these problems, teacher should prepare all learning tools, before starting teaching activity. In addition, teacher can use music, so students do not bored and the emotions of students and teacher get closer.

\section{Conclusion}

Based on field research and sources that have been processed, and discussed in previous chapters in depth, it can be deduced as follows:

1. In the application of Quantum Teaching method in SDN Bakalrejo 2. There are several impacts of the application of Quantum Teaching Method, namely, the spirit and pleasure of students in learning.

2. The problem of implementation Quantum Teaching method providing students with an understanding of the purpose of the lesson and the material being taught, as the ability of each student to understand is different. Furthermore, it provides a stimulation or example of the material to be conveyed. It is also difficult to find relevant media in learning.

\section{References}

Ahmadi, Abu. 2008. Sosiologi Pendidikan, Jakarta: PT. Rineka Cipta, 1991 Bogdan, Taylor Basrowi, dan Suwandi, Memahami Penelitian Kualitatif, Jakarta: Rineka Cipta.

Arikunto, suharsimi. 2003. "Dasardasar evaluasi pendidikan". Jakarta: Bumi Aksara. 
A'la, Miftahul. 2010. Quantum Teaching. Yogyakarta: Diva Press.

Arikunto, suharsimi. 2010. "prosedur penelitian: suatu pendekatan praktis". -cet. 15 - Jakarta: Rineka Cipta.

Arikunto, S (2002). Prosedur Penelitian, Suatu Pendekatan Praktek. Jakarta: PT Rineka Cipta.

Basuki, Sulistyo. 2010. Metode Penelitian. Jakarta: Penaku.

Bobby De Porter, Mark Reardon dan Sarah Singer-Nourie. 2005. Quantum Teaching: Mempraktikkan Quantum Learning di Ruang-Ruang Kelas. Terjemahan: Ary Nilandari, Bandung: Kaifa.

English in Elementary School. 2013. Teaching Material Collection.

Hasan, M. Iqbal. 2002. Pokok-pokok Materi Metodologi Penelitian dan Aplikasinya, Ghalia Indonesia, Bogor.
Joko Subagyo, P. 2006. Metode Penelitian Dalam Teori Dan Praktek. Rineka Cipta. Jakarta.

Moleong, Lexi J. 2010. Metode Penelitian Kualitatif. Bandung: PT. Remaja Rosdakarya.

Nata, Abudin. (2002). Manajemen Pendidikan; Mengatasi Pendidikan Islam di Indonesia. Bogor: Kencana.

Prastowo, Andi. 2012. Panduan Kreatif Membuat Bahan Ajar Inovatif. Yogyakarta: Diva Press.

Sugiyono, 2009. Metode Penelitian Kualitatif, Kuantitatif, dan RED. Bandung: Alfabeta.

Suyanto, Kasihani K.E. 2010. "English for young learners: melejitkan potensi anak melalui English class yang fun, asyik, dan menarik". -cet. 3 - Jakarta: Bumi aksara.

Thohir, Muhamad. 2012. "TRAINING QUANTUM TEACHING: menciptakan kelas yang bergairah". ASA BANGSA 